\title{
Pethő Szilvia
}

\section{Az intuíció' mint humán tényező feltérképezése, fejlesztésének lehetőségei a repülésbiztonság hatékonyságának növeléséhez}

A repülés egy olyan összetett tevékenyég, amelyben az emberi tényezöknek kiemelt jelentősége van. Az emberi hiba vagy az adott probléma észlelésének elmaradása balesethez, katasztrófához vezethet. Vizsgálatom során arra keresem a választ, hogy abban az esetben, ha a repülögépet vezető pilóta vagy a légiforgalmi irányító képes lenne, hogy a baleset bekövetkezte elött megérezze a fenyegető veszély jelenlétét és képes lenne annak megfelelően cselekedni, akkor megelőzhetővé válhatna-e a negatív kimenetel? Emiatt fontos kérdés lenne arra választ kapni, hogy a pilótajelöltek és légiforgalom-irányitó jelöltek kiválogatásánál figyelembe lehetne-e venni azt a tényezőt, hogy az intuitiven racionálisan döntö emberek kellő gyakorlattal hatékonyabban képesek lennének elhárítani a baleseteket? Megfelelő gyakorlati tesztek bevezetésével képesek lehetnénk-e kiszürni a jelöltek közül azokat, akik ilyen képességekkel rendelkeznek? Képesek lehetnénk-e e képesség fejlesztésére? Ami a gyakorlatban a negatív kimenetelü repülési események számának csökkenését tudná eredményezni.

Kulcsszavak: intuíció/megérzés, humán tényező, repülés, pilótajelölt, légiforgalmi irányítójelölt, egorugalmasság, észszerüség-megérzés, Firstbeat, Muse, barokamra, szimuláció

\section{Bevezetés}

2004-től foglalkozom a hagyományos orvoslás mellett a betegek holisztikus szemléletű gyógyításával. A betegeim gyógyítása során és a magánéletemben is többször kerültem olyan döntési helyzetbe, amely során a racionális gondolkodásomat kiegészítve a megérzésekkel jóval előnyösebb döntésre sikerült jutnom, mint azok nélkül. Később tanulmányoztam a témával kapcsolatos szakirodalmat és tudatosan elkezdtem megfigyelni a hasonló döntési helyzeteimet és tudatosan kezdtem alkalmazni a megérzések adta lehetőségeket. A jelen vizsgálat során két kérdőív, egy teszt és egy részletes előzményi felmérés kitöltésével a pilóták és pilótajelöltek, valamint a légi forgalmi irányítók és irányítójelöltek csoportokra való elkülönítését követően szeretném felmérni, hogy kik tartoznak a csak racionálisan gondolkodó és döntéshozó, és kik tartoznak a megérzés alapon is gondolkodók közé. A kiválogatást követően azok a pilóták és jelöltek, akik vállalják, barokamrában egy szimulációs technika segítségével közel valós 
környezetben fognak két szimulációt lerepülni, különböző időpontokban. A repülések során kollégáimmal rögzítjük a fontosabb életmüködési jeleket és az agyi hullámokat. A repülés után kikérdezem és rögzítem a tapasztalatairól a jelölteket. A légi forgalmi irányítók tesztelése pszichológiai módszerekkel fog történni. A vizsgálatok végén a rögzített adatokat és a tapasztalatokat összegzem a kutatás eredményeként. A jelöltek kutatásban való részvétele önkéntes.

\section{A megérzés definíciója}

Jung ${ }^{2}$ szerint egy tudatalatti képesség a lehetőségek észlelésére. Azaz miközben egy adott részproblémával foglalkozunk, látjuk az egészet is!

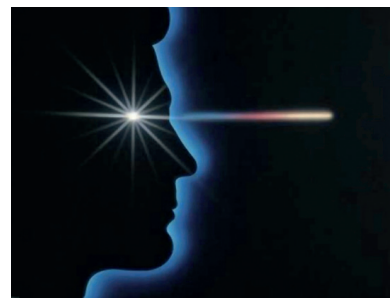

1. ábra

A megérzés sematikus ábrázolása [15]

\section{Példák}

\section{Saját tapasztalataim}

Egy melldaganatos beteg esete, amikor már percekkel előbb figyelmeztetett a megérzésem, hogy a betegnek rosszindulatú melldaganata van, mint mielőtt elmondta volna. Később miután a beteg beszámolt a panaszairól és elkészültek a képalkotó vizsgálatok egyértelmüen beigazolódott a diagnózis.

Akupunktúrás kezelések során a betegek visszajelzései alapján sokkal jobban érzik magukat kezelések után, ha nem csak a tanult ajánlások alapján választom meg az akupunktúrás szúrási pontokat, hanem a szúrás előtti pillanatokban jövő megérzésekre hallgatva választom azokat ki.

A 4-es főúton közlekedve nyomtam a féket, mert ez a figyelmeztető érzés jelentkezett miközben látszólag semmi sem indokolta volna, de a következő pillanatban egy szembe jövő kamion mögött közlekedő autó hirtelen előzésbe kezdett. Sikerült a megérzésemre hallgatva megakadályoznom a frontális ütközés bekövetkeztét ${ }^{3}$.

Ezek és az ehhez hasonló számtalan történet indított el abban, hogy elkezdjem a megérzésekről szóló irodalom felkutatását és mivel a „A légiközlekedés-biztonsághoz kapcsolódó

Jung: Carl Gustav Jung svájci pszichiáter, pszichológus, analitikus.

Dr. Pethő Szilvia (Dr. Szénási Szilvia): repülőorvos szakgyakornok, háziorvos, sportorvos, hagyományos kínai orvos (saját jegyzetek és az orvoslásban szerzett tapasztalatok). 
interdiszciplináris tudományos kutatási potenciál növelése és integrálása a nemzetközi kutatás-fejlesztési hálózatba a Nemzeti Közszolgálati Egyetemen GINOP-2.3.2-15-2016-00007" projektjében sportorvosszakértőként dolgozom, így e téma kiszélesítése a repüléssel kapcsolatban kifejezetten érdekessé vált számomra.

\section{Történelmi és egyéb példák}

Az Overlord4-hadmüvelet kapcsán Hitler nem hallgatott a megérzésére. Intuíciója azt sugallta, hogy a szövetségesek Normandiában kísérlik meg az inváziót, ám kivételesen hagyta, hogy a tábornokok többségi véleménye győzze meg.

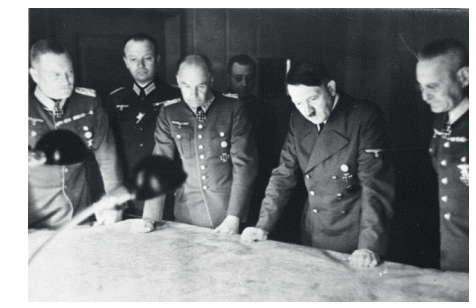

2. ábra

Az Overlord-hadmüvelet elötti tanácskozás [16]

Eugene $\mathrm{Kranz}^{5}$ feladata volt megteremteni az ürrepüléssel kapcsolatos döntésekhez szükséges környezetet és filozófiát. Ő képezte ki az irányítókat és az Apollo-116 Holdra szállásakor az ő feladata és felelőssége volt a holdraszállás irányítása. A feladat kapcsán többször került olyan helyzetbe, amikor a műszerek jelzései ellenére a saját megérzései kapcsán tovább engedte a leszállást, amely végül sikeres is lett.

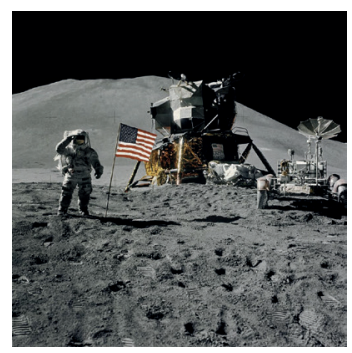

3. ábra

Holdraszállás [12]

Egy forma-1-es versenyző a pályán elsőként a cél felé haladva a befutó előtti szakaszban a megérzéseire hallgatva lefékezte autóját, annak ellenére, hogy látszólag semmi sem indokolta.

Overlord: Normandiai partraszállás-hadmüvelet.

Eugene Kranz: repüléstechnikai mérnök.

Apollo-11: Az Apollo-program ötödik ürutazókkal végrehajtott repülése az Apollo-11 volt. 
Azonban a cél előtti szakaszon több autó ütközött egymásnak, így megérzésére hallgatva elkerülte az ütközést. Az esetet később elemezve arra a felismerésre jöttek rá, hogy a befutó előtti szakaszon ülő nézők ahelyett, hogy őt ünnepelték volna, néma csendben vártak. A versenyző agya tudatosan nem dolgozta fel ezt a külső környezeti tényezőt, de az agy ősibb része feltehetően a tapasztalatai kapcsán már igen és ki is adta a figyelmeztető jelzést.

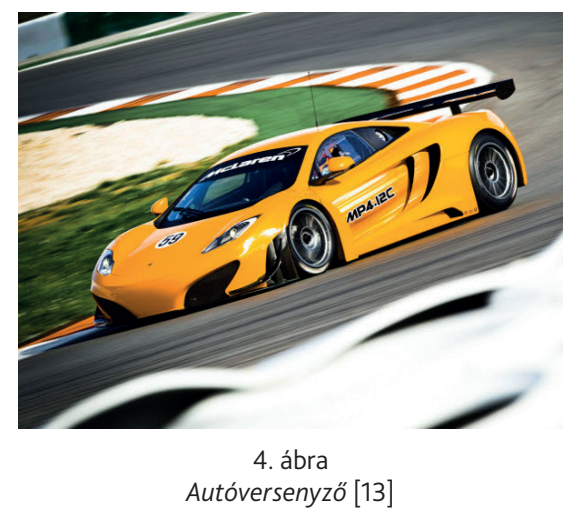

Barokamrai ${ }^{7}$ szimuláció vége előtt 4 perccel kollégánk érezte, hogy valami rossz fog történni, és ezt követően egy perc múlva leállt a számítógép, túlmelegedés miatt.

\section{Visszatekintés}

Az intuíció a latin intueri ${ }^{8}$ szóból származik, jelentése: megnéz, megtekint, megfigyel, belátni, rálátni. Időszámításunk előtt 7-6. század: próbálták a döntések okait megérteni és tanulni belölük például egy sikeres harc kapcsán. Arisztotelész ${ }^{9}$ szerint a közvetlen tudásra érzékeinken és tapasztalatainkon keresztül teszünk szert, tehát a tudományos feltevéseket és vizsgálatokat az intuíción keresztül lehet megérteni. Görög filozófusok szerint az intuíció olyan gondolat, megértés, amely nem következtetéseken alapul, ösztönös, amelyet az érzékszervek, a közönséges tapasztalat vagy egyszerüen az ész használata nélkül teszünk. A görögöktől kezdve a 17. századig az intuíciót összefüggésbe hozták a metafizikával, egyfajta módszernek tekintették a megfoghatatlan megragadására. Sigmund Freud ${ }^{10}$ szerint az emberi észlelés, gondolkodás a tudatalatti tevékenységekhez tartozik. Carl Jung szerint a tudatnak négy alapvető funkciója van: az érzékelés, a gondolkodás, az érzelem és az intuíció. Kant ${ }^{11}$ szerint az intuíció nem más, mint annak a felismerése, hogy a dolgok bizonytalanok. Ma: a termelés felgyorsulásával csökkent a dolgok megismerési ideje, ezért egyre nagyobb az igény az intuitív döntések iránt. Úgy tűnik azok a legsikeresebb emberek, akiknek érzéke van erre és ezt fel is használják

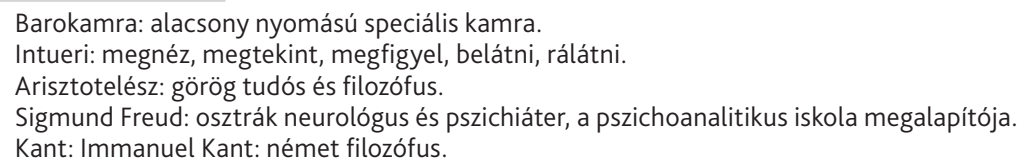


a döntéseik meghozatalához (Ron Schultz ${ }^{12}$ [5]). Douglas Dean és John Mihalasky ${ }^{13}$ 1960-ban 10 éves sikeres üzletemberekkel végzett kutatásuk eredményeként kiderítették, hogy az intuíció olyan készség, ami annál jobban érvényesül, minél fejlettebb valaki a vezetői ranglétrán.

Nem elég az intuitív döntési képesség, szükség van a tapasztalatra és a tudásra is, ami hozzájárul a teljes kép meglátásához, hiszen az intuíció ebből táplálkozik.

\section{A döntéshozatal}

\section{Alapjai}

Nincs két ugyanolyan probléma, de ami viszont egyforma, az a képesség, hogy az illető felismeri a lehetőségeket és azután a megfelelő irányt választja! Mi az, ami segíthet? A megérzések sora, amelyekre figyelve újabb lehetőségek nyílnak meg az agy kapacitásának kihasználásával, és a személyiség fejlődik [3].

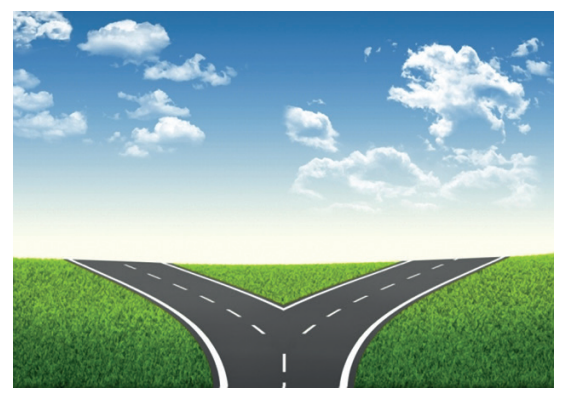

5. ábra

Döntéshozatal [14]

\section{A megérzések és döntések szerepe a repülésben}

A repülés egy olyan összetett tevékenység, gondolatok, cselekedetek sorozata, amely során bármikor bekövetkezhet a különböző tényezők együttes hibája, amely egy adott pillanatban balesethez, katasztrófához vezethet.

2 Ron Schultz: író.

13 Douglas Dean és John Mihalasky: kutatók, akik megpróbálták mérni és értékelni az intuitív tapasztalatok gyakoriságát és eredményeit a nagy, multinacionális vállalatok vezetői között, majd az adatokat feldolgozták. 


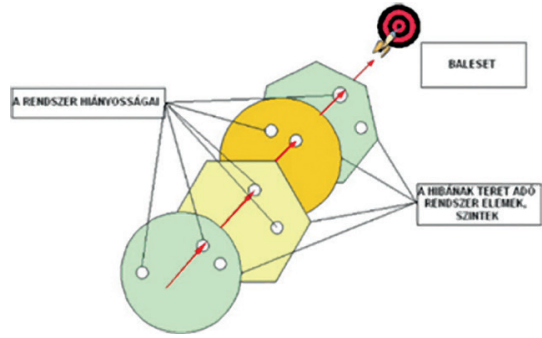

6. ábra

Sajt-modell ${ }^{14}[11]$

\section{A vizsgálat célja}

Abban az esetben, ha a repülőgépet vezető pilóta vagy a légiforgalmi irányító képes lenne arra, hogy a baleset bekövetkezte előtt megérezze a fenyegető veszély jelenlétét és képes lenne annak megfelelően cselekedni, akkor megelőzhetővé válhatna a negatív kimenetel. Emiatt fontos lehetne már a pilótajelöltek és légi forgalmi irányító jelöltek kiválogatásánál figyelembe venni azt a tényezőt, hogy az intuitíven-racionálisan ${ }^{15}$ döntő emberek kellő gyakorlattal hatékonyabban képesek lehetnek elhárítani a baleseteket. Megfelelő gyakorlati tesztek bevezetésével képesek lehetnénk kiszürni a jelöltek közül azokat, akik ilyen képességekkel rendelkeznek, és képesek lehetnénk e képesség fejlesztésére is, ami a gyakorlatban a negatív kimenetelű repülési események számának csökkenését tudná eredményezni.

\section{A vizsgálat menete és eszközei}

Feltáró beszélgetést és kikérdezést követően, az észszerüség-megérzés kérdőív [2], az egorugalmasság kérdőív [4] valamint egy bal/jobb agyfélteki teszt ${ }^{16}$ segítségével felmérem a jelöltek gondolkodási, döntéshozatali sémáját, majd ez alapján létrehozom a vizsgálati csoportokat. Elképzeléseim szerint tapasztalt pilóta, tapasztalt légi forgalmi irányító, pilótajelölt és légi forgalmi irányító jelöltekre. A csoportokon belül kiemelt fontosságú lesz, hogy mely jelölt tartozik a megérzés típusú és mely jelölt a racionális gondolkodásúak közé. Továbbá szükséges lesz elkülöníteni azokat is, akik képesek megérzés alapon változtatni az alapvetően racionális gondolkodási sémájukat. A vizsgálati csoportok kialakítását követően a pilóták és a pilótajelöltek barokamrában, közel élethű körülmények között fognak egy eseménymentes és egy balesethez vezető szimulációt lerepülni. A repülés alkalmával rögzíteni fogjuk a jelölt főbb életjelenségeit. Firstbeat-készülék ${ }^{17}$ segítségével a szív tevékenysége, a pulzusvariancia ${ }^{18}$, a Muse

14 Sajt-modell: A modell alapja annak elfogadása, hogy az ember hajlamos a hibára. Amikor valaki vagy valakik a repülés rendszerében követnek el hibát, ezzel befolyásolva a repülés biztonságát.

15 Racionális: ésszerü, értelmes, célszerü.

$16 \mathrm{Bal} / j o b b$ agyfélteki teszt: megmutatja, hogy az adott személy melyik agyféltekét használja jobban.

Firstbeat-készülék: A szív múködését rögzítő eszköz.

18 Pulzusvariancia: a szívritmus változása. 
készülék ${ }^{19}$ segítségével az agy tevékenysége, az ujjra helyezett és a homlokon elhelyezett mérők segítségével a vér szaturációját ${ }^{20}$ regisztráljuk. Az eseménymentes repülés kapcsán a jelölttől a vizsgálat végén nem várok megérzést, míg a baleset-kimenetelü szimuláció alkalmával igen, kifejezetten a baleseti szituációt megelőző periódusban.

\section{Egorugalmasság}
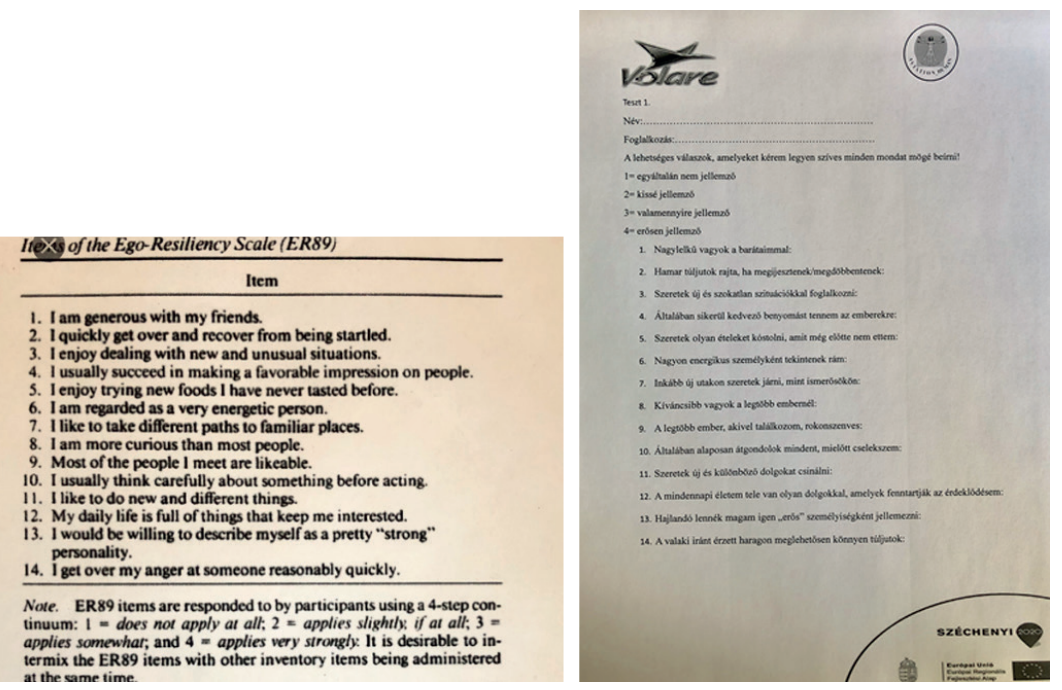

7. ábra

Egorugalmasság kérdőív [eredeti, saját szerkesztés]

Az egorugalmas személyek nagymértékben alkalmazkodók a környezeti változásokhoz és képesek arra, hogy ennek függvényében szabályozzák viselkedésüket. Azok az egyének, akik kevésbé rugalmasak, nem tudnak ilyen jól adaptálódni a hirtelen változásokhoz, mivel kevésbé képesek hatékonyan változtatni a kontroll szintjét a szituáció ${ }^{21}$ kívánalmainak megfelelően [1].

Az egorugalmasság alapján az egyének különböznek egymástól:

* magas rugalmasságú személyek jó problémamegoldók, jól tudnak alkalmazkodni a környezeti elvárásokhoz;

* alacsony rugalmasságúak: hajlamosak leragadni, kevésbé jó problémamegoldó képességgel rendelkeznek.

\footnotetext{
Muse-készülék: Az agyi hullámok rögzítésére képes eszköz.

Szaturáció: oxigéntelítettség.

Szituáció: helyzet, állapot, körülmények.
} 


\section{Az észszerüség-megérzés kérdőív}

Az észszerűség-megérzés kérdőív (Rational-Experiential Inventory; REI22)[2], [4] és az egorugalmasság összefüggései azt mutatják, hogy az egorugalmas emberek egyaránt magas pontszámokkal rendelkeznek az észszerüség és a megérzés skálán is.

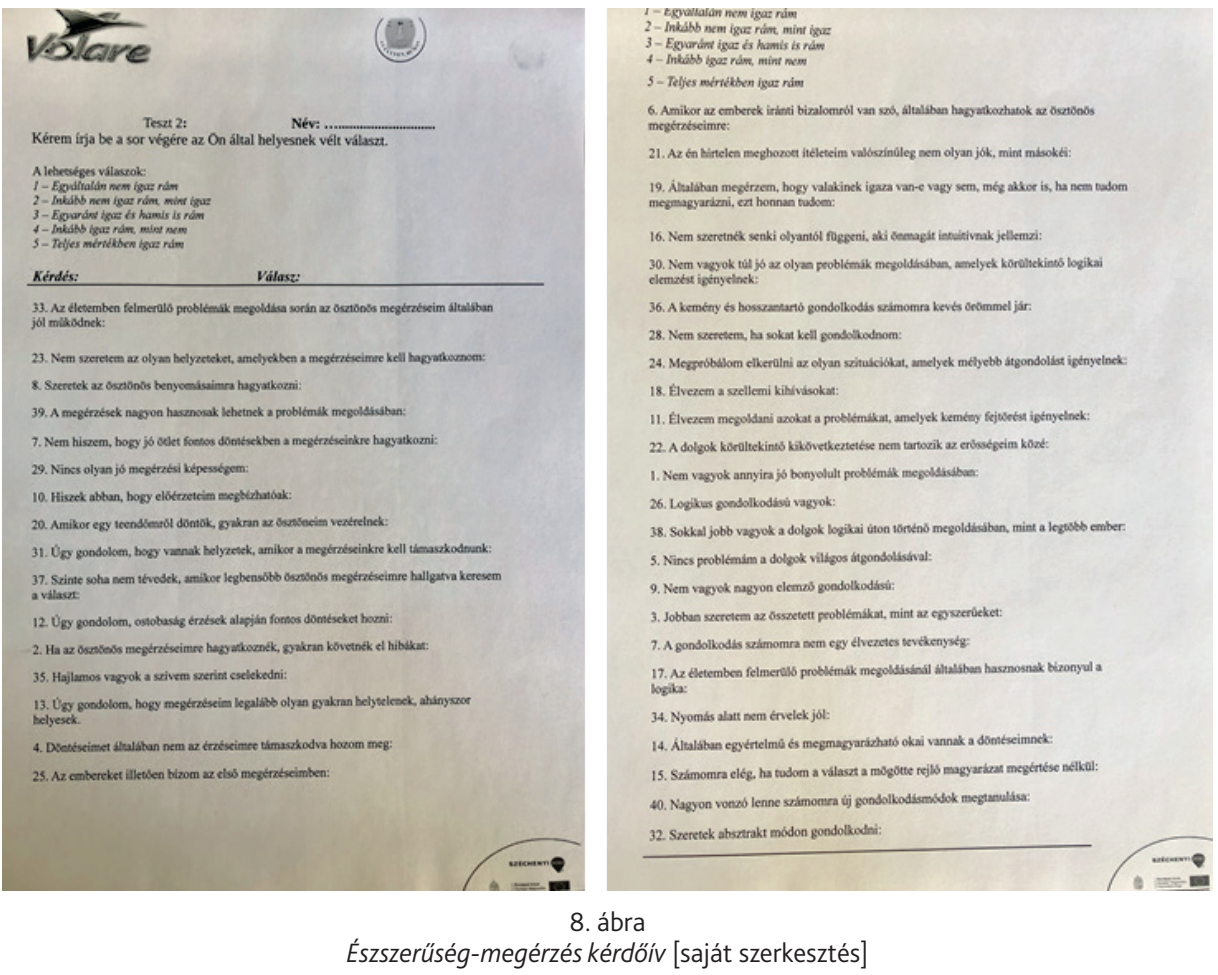

\section{Bal és jobb agyfélteki tesztek}

A bal és jobb agyfélteke eltérései:

* a bal agyfélteki domináns ${ }^{23}$ egyéneket a racionális, értékelö, logikus gondolkodás jellemzi. Az ebbe a csoportba sorolható döntéshozók jellemzően a tényekre, adatokra és a dolgok időbeni lefolyására koncentrálnak;

* a jobb agyfélteki gondolkodás segíthet a bizonytalanság, a kockázat elfogadásában és támogathatja a problémamegoldás intuitív, elképzelésekre alapozott válfaját. Ily módon a jobb agyfélteke domináns döntéshozók a bonyolultabb problémákra is találnak megoldást [5], [9].

22 Rational-Experiential Inventory; REl: észszerüség-megérzés kérdőív.

23 Domináns:. uralkodó, meghatározó. 

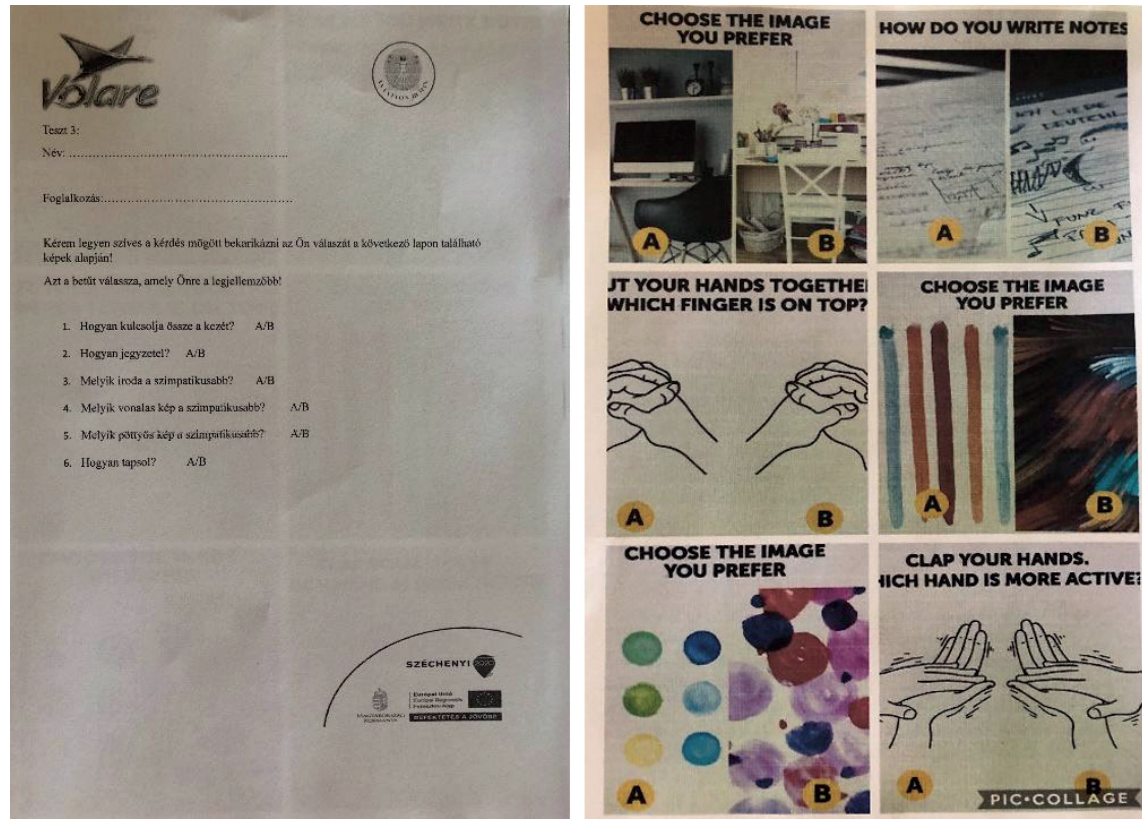

CLAP YOUR HANDS. IICH HAND IS MORE ACTIVE:

9. ábra

Bal és jobb agyfélteki tesztek [saját szerkesztés]

\section{Firstbeat-készülék}

Ez a vizsgálat egy pulzusvariancia alapú mérés és elemzés, ami képes megmutatni a szervezetet ért stresszt, feltöltődést, fizikai aktivitás és alvásminőséget. A barokamrai kísérleti repülés alkalmával a közel valós repülési szimuláció, a szervezetet ért hatások alapján képes arra, hogy a várt megérzés időtartamában rögzítse a pulzusvariancia változását és összehasonlítási alapot képezzen az eseménymentes repülés időtartalma során rögzített értékekkel.

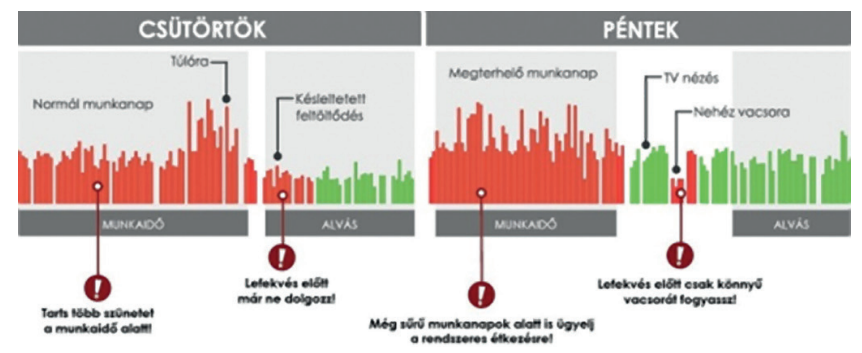

10. ábra

Firstbeat HR-értékelése [8] 

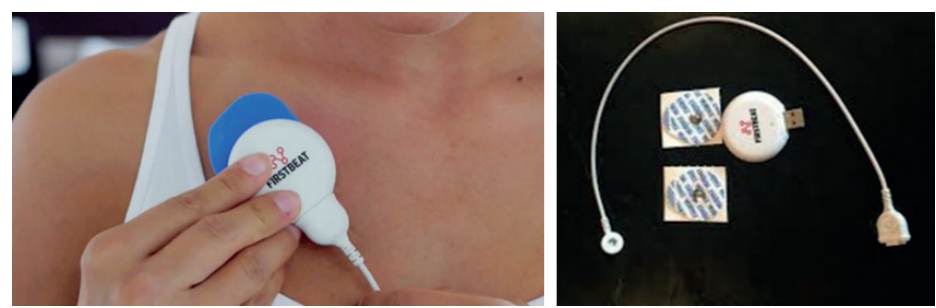

11. ábra

Firstbeat-készülék felhelyezése és összetétele [8]

\section{Muse-készülék}

A Muse-készülék müködését $\mathrm{EEG}^{24}$-szenzorok biztosítják, három található belölük a fejpánt homloki részén és egy-egy a fülek mögött. Az EEG (elektroenkefalográfia) az agy elektromos aktivitását méri. Az egészségügyben az agyi diszfunkciók, például az epilepszia vizsgálatára használják. Az agy folyamatosan elektromos jeleket generál amikor gondolkodik, alszik vagy ellazult állapotban van. Ezeket a jeleket a fejen szenzorokkal lehet érzékelni. A MUSE ugyanazon az elven működik, amit az orvosok és kutatók használnak az agyhullámok mérésére. A fejpántnak 7 kalibrált elektródája van. 2 a homlok két oldalán, 2 a fül hátsó területén, és további 3 referenciaelektróda a homlok közepén található, amelyhez az agy elektromos aktivitását detektálják. A barokamrai kísérleti repülés alkalmával a közel valós repülési szimuláció, a szervezetet ért hatások alapján képes arra, hogy a várt megérzés időtartamában rögzítse az agyi hullámok változását és összehasonlítási alapot képezzen az eseménymentes repülés időtartalma során rögzített értékekkel.
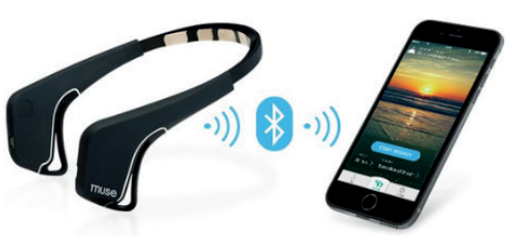

12. ábra

Muse-készülék felhelyezése és jelátvitel [7]

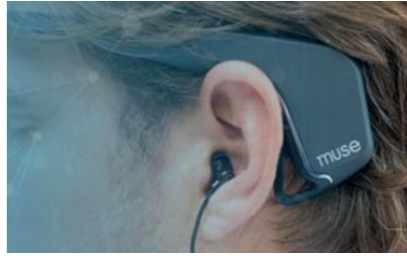

24 EEG: elektroenkefalográfia, az idegsejtek elektromos aktivitásának regisztrálására szolgál valós időben. 


\section{Barokamrában végzett szimulált repülés}

A jelöltek a RAVGYI ${ }^{25}$-ban található barokamrában 5500 m repülési magasságban végzik el a szimulált repüléseket. Speciális, erre a célra kialakított számítógép, monitor, virtuális szemüveg kiegészítéssel és repülési programmal. ${ }^{26}$
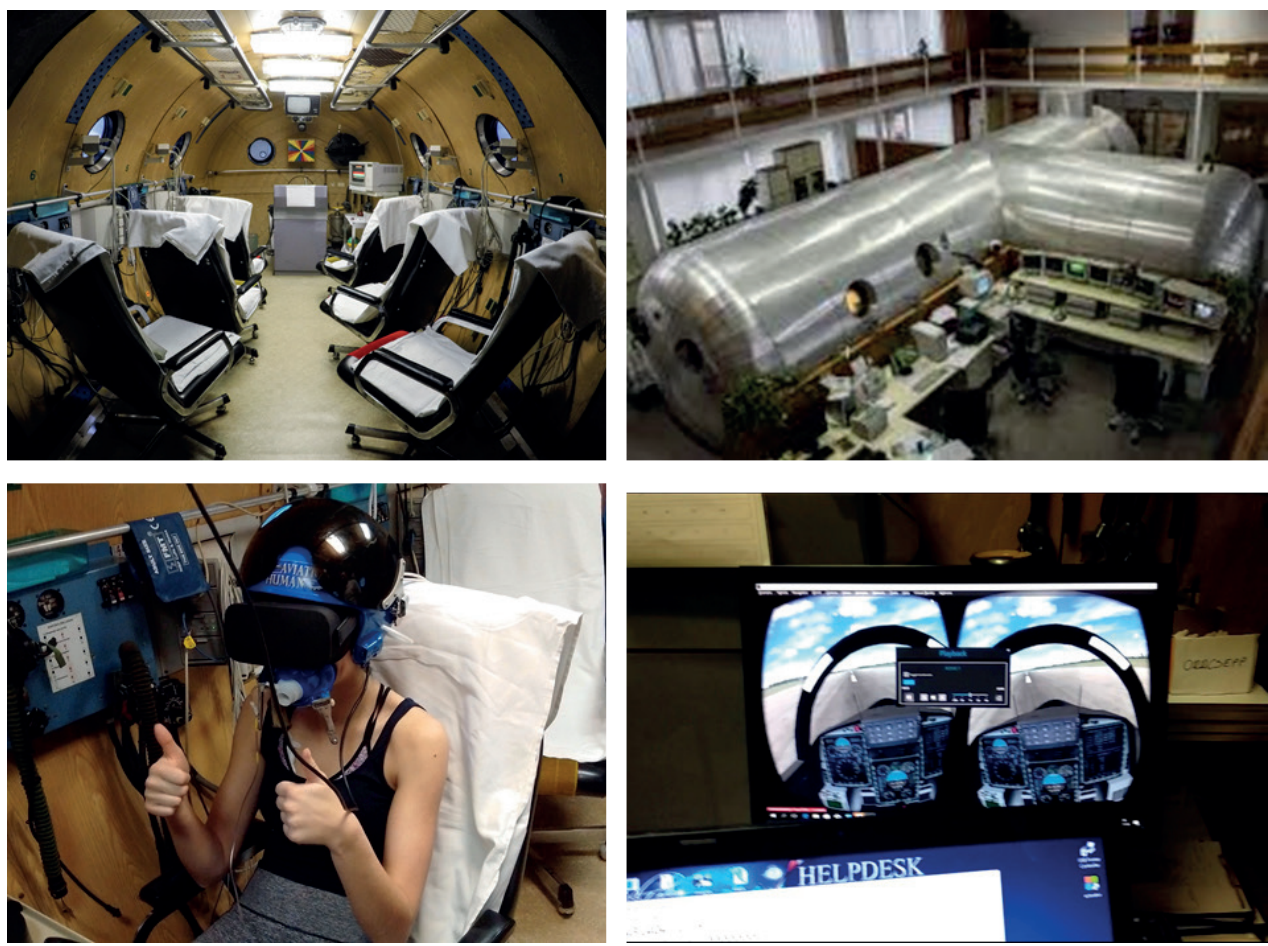

13. ábra

Barokamra szerkezete, jelölt és az eszközök elhelyezkedése [10]

\section{Összefoglalás}

A vizsgálat során a feltáró beszélgetést és kikérdezést követően, két kérdőív segítségével, azaz az észszerűség-megérzés kérdőiv, illetve az egorugalmasság kérdőív, továbbá a jobb/bal agyfélteki tesztek felhasználásával a pilóták és pilótajelöltek, valamint a repülésirányítók és repülésirányító-jelöltek csoportokra való elkülönítése az alapján, hogy kik tartoznak a tapasztalt/ tapasztalatlan vagy csak racionálisan gondolkodó és döntéshozó és kik tartoznak a megérzés alapon racionálisan gondolkodók közé. A továbbiakban a jelöltek a barokamrában a szimulációs technika segítségével közel valós környezetben fognak két szimulációt lerepülni. Az egyik

25 RAVGYI: Magyar Honvédség Egészségügyi Központ Repülőorvosi-, Alkalmasságvizsgáló és Gyógyító Intézet, Kecskemét.

26 A speciális szimulációs repülési program megalkotója Domján Károly MsC, Magyar Honvédség Légi Vezetési és Irányítási Központ Híradó Informatikai Osztály. 
repülés eseménymentes, míg a másik egy baleseti szituációt fog megjeleníteni számukra. A jelöltekre rögzített eszközök segítségével válik megfigyelhetővé az agyi hullámok, a pulzusvariancia, a homloklebenyi és végtagi oxigénszint-változásban bekövetkezett eltérések. A vizsgálat célja, hogy a pilótajelöltek kiválogatásánál figyelembe lehessen venni azt a tényezőt, hogy az intuitíven-racionálisan döntő emberek kellő gyakorlattal hatékonyabban képesek lehetnek elhárítani a baleseteket.

Gondolataimat az alábbi idézettel szeretném lezárni:

„Az ember általában érzi azt, hogy valami nem gömbölyü, felvillan benne a kétség szikrája; ez a legutolsó intő jel. Ha csak egy szikra kétséged is támad a hirtelen elhatározott manővert illetöen, ha egy hangyányit is bizonytalan vagy, hogy szabad-e, lehet-e, tudom-e, akkor már biztos lehetsz benne, hogy nem szabad! nem lehet! Ne söpörd el ezeket a megérzéseket. Röviden és nagy betükkel csak annyit kérek: VIGYÁZZ!"27 [6]

\section{Felhasznált irodalom}

[1] I. Winkler Dr., „A rugalmasság szintjei: a percepciótól a személyiségig,” BME TTK, Kognitív Tanszék, [Online]. Elérhető: http: //doktori.bme.hu/bme_palyazat/2013/honlap/ Farkas_David.htm

[2] J. Bognár, G. Orosz, és N. Büki, „Az észszerüség-megérzés kérdőív magyar adaptációja és az egorugalmassággal mutatott összefüggései," Pszichológia, 34. évf. 2. sz. pp. 129-147, 2014. DOI: https: //doi.org/10.1556/Pszicho.34.2014.2.3

[3] Z. Zoltayné Paprika, „Elemzés vagy megérzés: a stratégiai döntéshozatal gyakorlata Californiában és Magyarországon," Budapesti Corvinus Egyetem, 2008. [Online]. Elérhető: http: //real.mtak.hu/2690/1/68799_ZJ1.pdf

[4] S. J. Handley, S. E. Newstead, and H. Wright, "Rational and experiential thinking: A study of the REI," in International Perspectives on Individual Differences, R. J. Riding and S G. Rayner, Eds. USA: Ablex, 2000.

[5] R. Schultz, Megérzés és döntés. Network Twenty One Hungary, 1996.

[6] O. Daka, „Pilóta vagyok - élő pilóta,” iho.hu, 2011. [Online]. Elérhető: http: //iho.hu/hir/ pilota-vagyok-elo-pilota

[7] „Muse - meditációs fejpánt," muserelax.hu, [Online]. Elérhető: http: //muserelax.hu

[8] „Firstbeat," firstbeat.com, [Online]. Elérhető: www.firstbeat.com

[9] R. L. Atkinson, R. C. Atkinson, E. E. Smith, és D. J. Bem, Pszichológia. Budapest, Osiris, 1993.

[10] RAVGYI: Magyar Honvédség Egészségügyi Központ Repülőorvosi-, Alkalmasságvizsgáló és Gyógyító Intézet, Kecskemét.

[11] S. Klein, Munkapszichológia, I-II. Budapest: SHL Hungary Kft. 1998. p. 615-616.

[12] „Örökségvédelem alá helyeznék az első Holdra szállás helyszínét," librarius.hu, [Online]. Elérhető: https: //librarius.hu/2019/07/20/oroksegvedelem-ala-helyeznekaz-elso-holdra-szallas-helyszinet/

[13] „Gyengébb a McLaren versenyautó, mint az utcai,” automotor.hu, [Online]. Elérhető: www.automotor.hu/sport/gyengebb-a-mclaren-versenyauto-mint-az-utcai-375248/

27 Daka Olga: ma élő, aktív pilótanő. 
[14] „Döntéshozatal - segítséggel II.," das.hu, [Online]. Elérhető: https: //das.hu/ jogi-esetek-es-hirek/donteshozatal-segitseggel-ii/

[15] Székesfehérvári Reiki Klub, „Leromlott intuíció,” [Online]. Elérhető: https: //reiki.timba. biz/leromlott-intuicio/

[16] T. Elter, „Hitler megérzései ellenére sem hallgatott a Sivatagi Rókára,” origo.hu, [Online]. Elérhető: www.origo.hu/tudomany/20161115-szazhuszonot-eve-szuletett-erwin-rommel-vezertabornagy-a-masodik-vilaghaboru-egyik-leghiresebb.html

\section{MAPPING INTUITION AS A HUMAN FACTOR AND DEVELOPING IT IN ORDER TO INCREASE AVIATION SAFETY}

Aviation is a complex activity in which human factor has a major importance. Human failure or missing to perceive the given problem may lead to accidents and catastrophe. In my research, I am looking for the answer to the following question: provided that before the accident the pilot or the air traffic controller were able to feel the dangers looming ahead and acted accordingly, could negative outcome be prevented? By selecting pilot and air traffic controller candidates, could we take it into account that people making a decision intuitively-rationally, would be able to avoid accidents effectively? Introducing the proper tests, could we sort the candidates who have these qualities? Could we improve these qualities? It would result in decreasing the number of aviation events with negative outcome.

Keywords: intuition, human factor, aviation, pilot candidate, air traffic controller candidate, ego-flexibility, rationality-divination, simulations

Dr. Pethő Szilvia (Orvosi név: Dr. Szénási Szilvia) Orvos

Nemzeti Közszolgálati Egyetem doktorszenasiszilvia@gmail.com

https://orcid.org/0000-0002-7480-3063
Szilvia Pethő, Dr.

Doctor

National University of Public Service

doktorszenasiszilvia@gmail.com

https://orcid.org/0000-0002-7480-3063 
A GINOP 2.3.2-15-2016-00007 „A légiközlekedés-biztonsághoz kapcsolódó interdiszciplináris tudományos potenciál növelése és integrálása a nemzetközi kutatás-fejlesztési hálózatba a Nemzeti Közszolgálati Egyetemen - VOLARE" című projekt az Európai Unió támogatásával, az Európai Regionális Fejlesztési Alap társfinanszírozásával valósul meg.

A kutatás a fenti projekt „AVIATION_HUMAN” nevü kiemelt kutatási területén valósult meg.

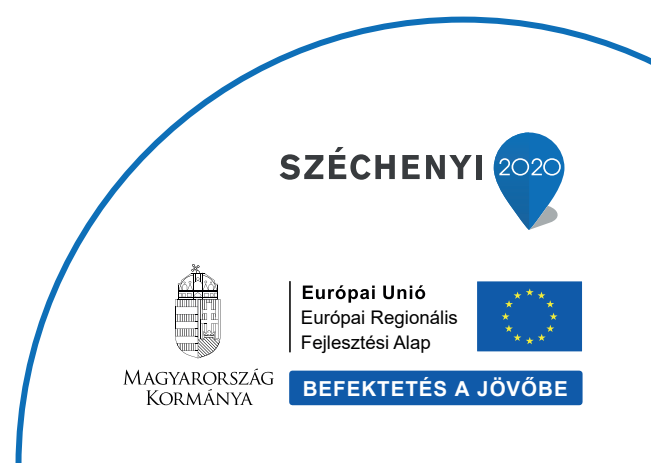

\section{口+15t5

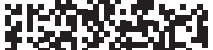 \\ .

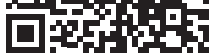

http://journals.uni-nke.hu/index.php/reptudkoz/article/view/338/171 